\title{
ISLAM, CHRISTIANITY AND THE MYSTIC JOURNEY
}




\section{Other books by Ian Richard Netton}

Across the Mediterranean Frontiers (ed. with D. A. Agius)

Allāh Transcendent: Studies in the Structure and Semiotics of Islamic Philosophy, Theology and Cosmology

The Arab Diaspora: Voices of an Anguished Scream (ed. with Z. S. Salhi)

Arabia and the Gulf: From Traditional Society to Modern States (ed.)

Encyclopaedia of Islamic Civilization and Religion (ed.)

Al-Fārābi and his School

Golden Roads: Migration, Pilgrimage and Travel in Mediaeval and Modern Islam (ed.)

Islam, Christianity and Tradition: A Comparative Exploration

Islamic and Middle Eastern Geographers and Travellers (4 vols) (ed.)

Islamic Philosophy and Theology (4 vols) (ed.)

Middle East Materials in United Kingdom and Irish Libraries: A Directory (ed.)

Middle East Sources (ed.)

Muslim Neoplatonists: An Introduction to the Thought of the Brethren of Purity (Ikhwān al-Ṣafä')

A Popular Dictionary of Islam

Seek Knowledge: Thought and Travel in the House of Islam

Studies in Honour of Clifford Edmond Bosworth, volume I: Hunter of the East: Arabic and Semitic Studies (ed.)

Șüfi Ritual: The Parallel Universe

Text and Trauma: An East-West Primer 


\title{
ISLAM, CHRISTIANITY AND THE MYSTIC JOURNEY
}

A COMPARATIVE EXPLORATION

\author{
$\bullet$ \\ IAN RICHARD NETTON
}

EDINBURGH UNIVERSITY PRESS 
(C) Ian Richard Netton, 20I I

\section{Edinburgh University Press Ltd 22 George Square, Edinburgh www.euppublishing.com}

Typeset in Goudy by Koinonia, Manchester, and printed and bound in Great Britain by CPI Antony Rowe, Chippenham and Eastbourne

A CIP Record for this book is available from the British Library

ISBN 978 O 748640829 (hardback)

ISBN 978 O 7486 408 I 2 (paperback)

The right of Ian Richard Netton to be identified as author of this work has been asserted in accordance with the Copyright, Designs and Patents Act 1988. 